\title{
Capital, Neoliberalism and Educational Technology
}

\section{Chris Jones ${ }^{1}$}

Published online: 23 April 2019

(C) Springer Nature Switzerland AG 2019

I have been asked by experienced colleagues what neoliberalism means and why it is relevant in educational technology. To me, the link seems obvious but let me set out some of the links between neoliberal political economy and educational technology. Educational technology has a relatively long history (Cuban 1986) and this commentary is restricted to computing and digital technologies in education. Currently, digital technologies are established features throughout education. Indeed, the core digital presence of many educational institutions is the Learning Management System (LMS) (Virtual Learning Environment, or VLE, in the UK). These systems retain many of the features found in early applications of computer conferencing and even their look and feel has not moved on significantly since the introduction of a graphical user interface (GUI). The really significant advances in technologies have been in devices, networks and memory, with a movement from desktop personal computers and mainframe computers to mobile phones and tablets connected to high-speed networks and the cloud. Institutional islands and dial-up facilities have changed to high-speed broadband networks accessed via mobile and Wi-Fi connections linked to extensive storage. Technological changes are sometimes seen as the dominant driver of social change, a kind of technological determinism. However, in the same time period that technology changed, there was a political and economic transformation of the world economy from a competition between capitalism and socialism, with a developing 'third world', to a single global system differentiated into geographical regions and nation states. Capital is triumphant, the economy is global in scope and the state has been reduced in the face of resurgent markets. Perhaps, surprisingly, there has been little focus on the relationships between the global resurgence of capital, in market-led neoliberal forms and the characteristics of those educational technologies and institutions that emerged at the same time (for an exception see Selwyn and Facer 2013). This commentary addresses that perceived gap by outlining possible connections between capital, neoliberal politics and educational technology and suggesting a revised educational response.

Chris Jones

C.R.Jones1@1jmu.ac.uk 
Neoliberalism builds on the early liberal idea of free markets and a laissez-faire economic order. Neoliberalism argues that non-market mechanisms are inefficient and that they lead to a lack of political, social and economic freedom (Hayek 1944). These ideas became mainstream thinking under the Presidency of Ronald Reagan in the USA and the Prime Minister of the UK, Margaret Thatcher. Their reforms in two advanced capitalist economies coincided with the market reforms of Deng Xiaoping in China, and in the 1990s, they were amplified by the collapse of the Soviet Union. A distinction between classic liberalism and its neoliberal form was the active role of the state. Liberalism reacted against the feudal state and struggled to free markets from state interference. Neoliberalism actively used the state to reset regulatory and political frameworks, to roll back the state's previous activities and to enforce market relations. The neoliberal state was not laissez-faire because it regulated to enforce market and quasi-market relations rather than stepping aside to allow transactions between private parties. In education, this meant the drive towards viewing students as consumers and in some cases the introduction of fees and competition between education 'providers'. The neoliberal nature of these changes was signalled by their introduction alongside market regulators through which the state actively encouraged certain outcomes. The catchphrases of the new state endorsed and enforced education systems were choice and competition. New systems of measurement and ranking were introduced to replicate the role of price in genuine markets. For choice to be effectively transmitted between purchasers and providers, systems of funding were devised allowing choices by students and parents to be translated into financial allocations between competitors. These cumbersome processes added significant transaction costs to the educational system and drove 'providers' to find new ways to engage with students and parents.

Technological changes in the late 1970s and 1980s moved computing away from mainframe large computers in specialised facilities to personal computers in the home and distributed throughout the economy. Associated with these technological transformations, a range of arguments have placed technology at the centre of social change. These arguments stress the effects of technology on society. Arguments for social shaping, in contrast, stressed the process of design and the purposes technologies were designed for. These conflicting outlooks can be reconciled by a socio-material understanding of technology in which technologies have a history in which social forces are embedded, and they are material artefacts with definite form, which are taken up in society in socially and politically informed ways. Technologies have persistent effects because they allow for or afford some outcomes rather than others and even when they are non-determining they have an influence inclining users to one outcome rather than another. A significant link between the political and economic form of neoliberalism and the technology it gives rise to can be found in the need to control labour. Technology provided a way to replace labour and to disrupt labour organisation (Harvey 2005).

Education is directly affected by neoliberal capitalism because of the changing occupational and social structure. New occupations demand new skill sets and the proportion of society requiring higher level education and skills has increased as a proportion of the population. While there are arguments about the usefulness of degree level qualifications, there is a general assumption that an advanced economy based on new technologies requires a highly educated workforce. The new workforce is said to require 'team' working and new forms of cooperation and collaboration at work. The 
flat organisational forms and reduced hierarchy characteristic of modern organisations require workers to be more self-motivated and self-organising. The contradictory process of de-skilling and re-skilling the workforce, and the development of complex global production networks gives rise to independent and semi-independent producers, organised in modular networks, alongside independent professionals and consultants. These changes have led to different kinds of demands being placed on education, in particular, to develop students with competences fitted to the new work conditions with what is often described as digital literacy.

The information age and the network society are decentralised and the history of computing mirrors the neoliberal arch in both historical time and dialectical process. The decentralised structures of mature network societies rely upon a history of centralised public funding for their foundations. It was state funding, often military in character, that developed the technological building blocks that became the basis of an apparently distributed, entrepreneurial and disruptive 'new' technology (Mazzucato 2013). It remains state action that protects and regulates the market in which the technological giants flourish. Fundamentally, public education provided the intellectual 'capital' on which technological advances were built and which helped to determine the geographical distribution of centres for new technology such as Silicon Valley. The distributed global network society displays a geographic clustering of innovation in distinct areas co-located with high-quality universities. To feed the new economy, schools and universities have gone through an unprecedented expansion and the education sector has become international and economically important in itself, with international flows being included as an 'export' in economic terms. Education is increasingly spoken of as a key enabler, if not the enabler, of development, innovation and economic growth.

Educational technology does not have the scale and scope to warrant a distinct role in technological developments. While many technologies arise in educational contexts, they are often developed and commercialised elsewhere and sold back to educational institutions as products. Education is a consumer of technologies developed for other purposes (e.g. Microsoft 365). At times, educational technology coalesces around issues with a wider social purpose, for example, early collaborative systems of groupware and computer conferencing (e.g. Lotus Notes) and currently 'learning' analytics and the application of data analytics to education. In the neoliberal system of choice by consumers, technological systems are deployed to facilitate competition between institutions by marketing, reducing student drop out and ensuring the reliability and comparability of results. This has led to the deployment of institutional technological infrastructures including Learning Management Systems (LMS-VLE), Enterprise Resource Planning (ERP) and plagiarism software (e.g. Turnitin). Education also relies upon a range of universal infrastructures which serve the wider public, such as Google, and these systems often have educational sub-sectors, e.g. Google Scholar and Google for Education. An increasing feature of educational engagement with technologies is the ways in which the institution itself becomes 'unbundled', with different aspects being absorbed into discrete technological systems. These systems are provided by global corporations who extract data and expertise from the institutions and aggregate the data across the world. A recent example of 'disruptive' technology that was thought to challenge educational institutions was the development of Massive Open Online Courses (MOOCs). In their early incarnations, they were thought to be a potential 
replacement for traditional organisations in education, a technological disruptor. Only a few years later on from their height, the idea that free courses offered via online platforms could supplant universities and schools seems ridiculous, but this was a widely held view until recently.

The technologies and platforms developed by venture capital and large corporation have affected the kinds of work educational employees are engaged in and the kinds of students enrolled in education. Academic work has been affected by the general development of digital and networked technologies through the emergence of digital scholarship and the digital scholar. The student intake is said to be affected by their immersion in new technologies and there are repeated claims that new 'generations' of students are bringing practices developed by their exposure to new technology into student contexts. In previous times, it was the digital and the networked that were identified as motors for this change, more recently, it has been social media and the smartphone. Digital technologies are also said to be changing fundamental aspects of educational practice including what it means to learn, the routines of academic reading and the way study is conducted. Openness has become one of the key battlegrounds in the integration of new technologies into education because open educational resources (OER) can be seen as a public benefit, a way to reduce costs and increase access. However, OER can also be in alignment with the contemporary needs of capital in which the learner has to constantly seek new and relevant knowledge, to make themselves a more desirable, educated and flexible labour commodity. Openness has had two faces, one aligned with neoliberal markets and individualism, the other with a more anarchic anti-state libertarianism that prizes civic initiatives and self-help. The results of such progressive initiatives have in large part been disappointing. Open courseware, learning objects, Open Educational Resources, all worthy initiatives, reliant on voluntary labour, have not been able to develop to a scale that challenges venture capital and neoliberal practices. Open access to research has been a recent example in which governments have begun to intervene to ensure that publicly funded research is not held behind subscription walls by large academic publishers. It seems that to ensure even a modicum of success, bottom-up initiatives for openness require top-down support from the state.

The conclusion I draw from these interactions between a neoliberal political economy and educational technology is that educational reform will not come from technological change and it will not come from civic action and voluntary initiatives alone without state support. The Open University in the UK was set up by a progressive Labour Government in 1969 and it integrated the newest communication technologies. This hugely successful institution was proudly open to people, places, methods and ideas and it inspired many international comparators. It has struggled in recent years, its openness challenged by repeated regulatory restrictions and the introduction of fees in the UK higher education. The history of the Open University demonstrates how state action can galvanise progressive grassroots activity and build successful, innovative and advanced practical action. It also demonstrates decline through neglect and state regulation in a hostile economic environment. Critical digital education, and educational technology more broadly, needs to embrace aspects of classic political action. To develop pedagogies that mobilise new technologies successfully, educators need to work with traditional social and political actors to win them to a progressive educational programme of action. This will need engagement with political parties, trade 
unions and cooperative movements. It means adopting a top down alongside a bottomup perspective. Critical pedagogy needs to embed itself in political programmes that can be enacted at state and regional levels. Such an approach paradoxically mirrors the successful use of the state to enforce the reintroduction of markets and quasi-markets by neoliberal politicians.

\section{References}

Cuban, L. (1986). Teachers and machines: the classroom use of technology since 1920. New York: Teachers College Press.

Harvey, D. (2005). A brief history of neoliberalism. Oxford: Oxford University Press.

Hayek, F. (1944). The road to serfdom. Chicago: University of Chicago Press.

Mazzucato, M. (2013). The entrepreneurial state. debunking public vs private sector myths. London: Anthem Press.

Selwyn, N., \& Facer, K. (Eds.). (2013). The politics of education and technology. New York: Palgrave Macmillan. 